\title{
Queer Futures, National Utopias: Notes on Objects, Intimacy, Time, and the State
}

\author{
George Paul Meiu
}

On 17 May 2017, the International Day Against Homophobia, Transphobia, and Biphobia, the Goethe Institute in Nairobi displayed the work of six Kenyan artists in an exhibit provocatively named To Revolutionary Type Love: A Celebration of Queer Love. At the forefront of the exhibit was a remarkable collection of kanga fabrics. Kangas are cotton sheets ( 1 x 1.5 metres) imprinted with colourful geometrical and floral patterns and displaying, along their lower rim, a short proverb, riddle, or aphorism. Worn by women of different socioeconomic means, both in cities and the countryside, in a wide variety of ways, kangas are sartorial markers of an African modern identity anchored in respect for tradition (Amory 2017; Beck 2006; McCurdy 2006). Kenyan and Tanzanian elites have long used kangas as national folk dress items and, recently, some residents of the Swahili coast (for example Zanzibar) called on UNESCO to recognize these fabrics as their 'cultural heritage' (Boswell 20o6). Emblematic of tradition, kangas display proverbs that celebrate heteronormative love and marriage, their pleasures and intrigues.

For the exhibit, artist Kawira Mwirichia designed 22 kangas that called for affects and attachments that are more expansive and inclusive, more accepting of queerness. The artist dedicated each kanga to a different country in the world, decorating its surface with designs inspired from that country's history of LGBTQI+ activism. She then printed on each of them a saying in the Swahili language collected from members of the Kenya queer community. "Love is my religion, come worship with me,"1 reads one kanga as it seeks to divorce religion from homophobia. "Let's not bring hate into love," ${ }^{2}$ warns another. Yet others proclaim proudly, "My queerness is not a vice, not deliberate, and harms no one;" "Beautiful souls like us don't belong in closets;" or "I see a day where love shall be prosecuted nevermore."3

\footnotetext{
1 In Swahili, Huba ndo imani yangu, njoo tuabudu (English translation by the artist).

2 In Swahili, Tusilete chuki mapenzini (English translation by the artist).

3 In Swahili, Ushoga wangu si dhambi, sio chaguo, na haliumizani; Wazuri kama sisi, hatujitengi hatujifichi; Natabiri itakuja siku, hatutateswa kwa kupenda (English translations by the artist).
}

(C) GEORGE PAUL MEIU, 2022 | DOI:10.1163/9789004471641_027 
Turning a salient cultural object long wedded to nationalist imaginaries of tradition and 'African morality' into a medium of queer activism, Mwirichia, I suggest, set out to imagine a different sort of future. According to the exhibit's catalogue, she hoped "to inspire and instil a sense of self-love, pride, and wellbeing in our queer community here in Kenya as it reaches out to the world." In an interview with the national newspaper the Standard, the artist expressed her wish for a day when her work "might be considered this different and powerful thing that came out of Kenya and spoke on behalf of many marginalized people, people who should be accepted as part of the fabric of society". "My kangas stand for that," Mwirichia said, "a fabric of society" (Ombogo 2019).

Building on the homonymy between kanga fabrics and the fabric of society, Mwirichia's installation stages what I see as a ritual of future making. The artist told the Standard that her idea for the project came from attending a wedding. There, in an intriguing ceremony, women laid kangas on the floor and the bride walked on them. As she stepped forward, looking down, the bride encountered moral lessons inscribed as proverbs on these kangas. She would then carry their lessons into her marriage. Inspired by this ritual, the artist paved the exhibit hall's floors with the kangas she designed and, covering them in a transparent plastic sheet, invited guests to walk, like the proverbial bride, on them. In what resembles a rite of passage, visitors stepped into a space and time the artist had envisaged in conversation with the local queer community - a microcosm that, one might argue, insists on a different kind of future. Borrowing designs from other countries' queer activist traditions, the artist appropriates power from an extrinsic world, seeking to impart it to a marginalized Kenyan people. This ritual sets out, as the artist put it, to empower local queers "to reach out to the world."

I also wish to suggest that, using an object otherwise associated with tradition, the kanga installation claims queerness as customary, implicitly dismissing claims that homosexuality is somehow 'un-African'. Numerous politicians, religious leaders, and civil society groups have made this claim to denunciate same-sex intimacies as foreign and polluting (Epprecht 2007). Promising to secure heteronormative gender, family, and reproduction, they have described homosexuality as dangerous to nativist sexuality - a set of intimate norms claimed as timelessly autochthonous. With the help of the media, leaders and reformists spread the idea that rescuing nativist sexuality would grant people easier access to a respectable future (Cynn 2018; Makumbi 2018). Basile Ndjio (2016: 115) called this process the "culturalization of sexuality", a set of "enduring efforts by some African rulers to construct a more racialized and autochthonized form of sexuality" as a basis for citizenship. It is such attempts to codify, rescue, and reinforce nativist sexuality that Mwirichia subverts when 
she uses a customary object of nationalist, nativist utopia to envision what appears as a distinctly queer future.

Mwirichia's art can also inspire anthropologists to reflect on the importance of attending to queer future making practices, past and present, and of activating, through ethnography, their critical and transformative possibilities. 'Queer' must not refer here simply to a subjectivized sexual identity. Rather, the term can also designate modes of becoming that are, if not oppositional to, then out of line with normative expectations of intimacy, attachment, work, consumption, or respectability (Nyanzi 2014). This broader meaning also echoes Kenyan uses of the term. In a YouTube documentary, We Must Free Our Imagination, writer Binyavanga Wainaina (2014) recalls how, as schoolchildren, he and other pupils were not allowed to raise critical questions in class. "Here, to challenge a thing in class," Wainaina says, "is to be bringing, as my math teacher used to call it, queer behaviour." "That is very queer behaviour," he remembers his teacher say. Inflected perhaps with an older, Victorian sense of the term as 'disobedient' or 'out of line', this use of 'queer' may also apply to any futures that subvert the straight time of the life course, progress, or development. The term 'queer' is perhaps less commonly used in Kenya today. It is either invoked by older educated people in the sense that Wainaina discussed or adopted, of late, by mostly middle-class LGBTQI+ activists. More specific Swahili terms such as mshoga or msenge (for a gay male), and msagaji (lesbian), or the Ugandan neologism kuchu (gay), along with the English terms gay, lesbian, bisexual, or trans are far more common (van Klincken 2019: 104-8). But, for my argument, it will be useful to think with queer's simultaneously identitarian and nonidentitarian connotations. A young woman from Nairobi told me she identified as 'queer' rather than 'lesbian' because "I don't want to be put in a box," further suggesting the term's subversive connotations. Queer is thus about both LGBTQI+ people and 'out of line' moments and desires, spatial and temporal orientations. It is the meaning of queer, that queer theorists, for example, have used to describe temporal asynchronies as 'queer time' (Freeman 2007; Halberstam 2005) and the anticipation of non-reproductive times as 'queer futures'. What would it mean then, inspired by Mwirichia's kangas, to pay closer attention to 'queer futures' through ethnography?

In Cruising Utopia: The Then and There of Queer Futurity, José Esteban Muñoz (2009) uses the concept of the 'queer future' to reflect on the political currency of a certain kind of utopian imagination. This imagination can emerge when we turn to art, artefacts, practices, and places with the intent to recognize in 
their shapes and contradictions unrealized, emancipatory potentialities. Such potentialities can exist virtually as futures-past, paths not taken in foregone moments, but also - simultaneously - as 'not-yet-conscious futures'. "The not-yet-conscious," Muñoz argues, "is the realm of potentiality that must be called on, and insisted on, if we are ever to look beyond the pragmatic sphere of the here and now, the hollow nature of the present" (Muñoz 2009: 21). To recognize such potentiality, says Muñoz, "we may need to squint ... strain our vision and force it to see otherwise, beyond the limited vista of the here and now" (2009: 22). Hence, queerness is also what is "not quite here," "the thing that is not-yet-imagined" (2009: 21), "a field of utopian possibility ... in which multiple forms of belonging in difference adhere to a belonging in collectivity" (2009: 20). This understanding of queerness is important if we are to grasp normativity itself as a dialectical process. Normativity never simply is; it is neither singular nor given, neither fixed nor timeless. Rather, it exists as a struggle to sustain and reinvent itself, while identifying and excluding particular queer bodies and possibilities (Wiegman and Wilson 2015). Requiring the hard work of its constant reiteration, normativities are thus fragile, prone to ruptures and failure (Butler 2002).

It is precisely this fragility, the looming danger that heteropatriarchal norms can rupture (and often do), that the state has growingly promised to prevent by securing 'national values'. In an effort to legitimize their own raison d'être, since the early 1980s, numerous states across the world have deemed dangerous and promised to foreclose the possibilities of myriad queer futures (Alexander 1994). Liberal economic reforms prompted the devolution of government and the outsourcing of welfare to corporations and NGO s, intensified mobility; and mired claims to citizenship in anxieties over 'the foreign' (Ferguson 2006; Nyamnjoh 2006). In this context, the link between the nation and the state has come sharply into question (Comaroff and Comaroff 2001). As political leaders claim to rescue nativist (hetero)sexuality as national identity, for example, they seek to legitimize the state as the ultimate source of security for national values. It is then less surprising that the first decade of the new millennium saw a surge of homophobic rhetoric and violence in Africa and elsewhere (Bosia and Weiss 2013). Rather than speak of an essentialized 'African homophobia', a concept premised on a racist colonial construal of Africanity as alterity, queer African studies scholars have emphasized the importance of understanding homophobia both as part of the histories of particular states and in its wider political economic context (Awondo et al. 2012; M'Baye 2013; Ndjio 2016). To understand queer futures under these circumstances, it is necessary to engage critically with the state and its new forms of governance, in both their local and global instantiations. 
How then can queer futures materialize amid (or against) rising homophobic rhetoric and violence, or growing investment in national utopia, whether sexual or otherwise? And how can such futures be made manifest in a contemporary political economy so desperately invested in rescuing heteropatriarchal normativities? One might argue that the point of queer futures is surely not to materialize as imagined, but to produce collectivities sustained by the pursuit of their utopia; in other words, to offer themselves as objects of desire in the quest of which new, emancipatory social attachments can emerge. In Kenyan, Christian, Queer, Adriaan van Klinken (2019) illustrates this possibility compellingly for a context in which conservative Christian values could, in principle, too easily efface queer worlds. Drawing on Muñoz's notion of 'cruising utopia', he shows how, for many LG BTQ+ Kenyans, many of them Christian, imagining a queer future becomes a modality of world-making. Various kinds of activism through art - or, artivism, for short - including hip hop or storytelling, respond, he suggests, "to social and political homophobia ... presenting a range of lgbt-activist strategies and opening up alternative queer imaginations" (Van Klinken 2019: 17). The actualization of queer futures might be hard to envision under current circumstances. But a desire for it nevertheless sustains worldmaking, even if, in Nairobi, art works most efficiently as a means of political opposition primarily for middle-class and elite activists. Like emerging forms of queer African art, ethnographies of queer worlds in Africa have also proliferated in response to growing discrimination. ${ }^{4}$ Such studies have excellently captured modes of imagination, attachment, and affect that sustain potentialities of the kinds described by Muñoz. Like art, ethnographies can thus help us recognize virtual possibilities, paths not taken, not-yet-conscious futures.

What if we were to recognize that, with the historical transformations of late capitalism, much social life sustains queer articulations? That the making of otherwise normative futures often involves queer means, circumstances, and outcomes? Or that futures can be queer even when people seek to disavow, displace, and repudiate the queerness of their own actions, desires, and livelihoods, to reclaim the narrowly straight line of progress, development, and reproduction? And how would this simple realization change how we can understand the current politics of sexual nativism and national utopia?

4 Such ethnographic monographs include Dankwa (2021), Gaudio (2009), Lorway (2015), Reid (2013). 
With late capitalism, one can claim, futures in general have become queer. In 1980, Kenya's national newspaper, the Daily Nation, published a cartoon it called 'Forecaster's Map of the 1980s: Alternative Prognostications, 1980-89'. Designed by the World Future Society, "a Washington based association of people interested in what may happen during the years ahead," the map depicts futurity as confusingly rhizomatic. Rather than the straight line associated with the temporality of modernity, progress, and development (Koselleck 1979), the future figures as a net of numerous, intersecting, and diverting roads, streets, and alleys peppered with imaginatively named stops and destinations - for example, 'Status Quo Boulevard' leads through 'Great Depression' and 'Welfare State' to its final destination 'Chaos: War, Famine'. Smaller paths are called 'Refugee Crossing', 'Back to the Good Ol'Days', or 'Soft-tech Bypass' and lead respectively to 'Cybernia', '1970s', and 'Ecotopia'. Evocative of a sense of temporal disorientation and uncertainty at the time, the map's strong resonance with the realities of Kenyan life must have informed the editors' decision to reproduce it in their newspaper. Many Kenyans with whom I have spoken over the years are certainly aware that their futures are rhizomatic (see also Smith 2008), even if they do not necessarily celebrate such futures as ends themselves. Although the straight linear time of modernity and progress continues to inform ideals of respectability and ideologies of governance, it works in dissonance with the rhizomatic future of life-as-lived; and this dissonance is quite queer.

Mwirichia's kangas reminded me that, during my fieldwork, I had already encountered these fabrics, quite unexpectedly, as queerly entangled in the production of futures. Since 2008, I have worked in the town of Mtwapa on the Kenyan coast, pejoratively known as the country's 'sin city' for its sexual economies. Contrary to dominant narratives that see Kenyans who live or travel to Mtwapa as morally decadent, the town's residents - mostly migrants and migrant settlers - struggle to produce respectability while engaging in various kinds of 'illicit' work. Early on, one practice caught my attention. Women who engage in sex work at night, leave their homes in the evening and walk or ride motorbike cabs from their residential neighbourhoods (mtaa) to bars and clubs along the town's main road. For these short trips, they cover their mini-skirts or open blouses, which they wear to attract clients, with kanga fabrics. Upon arrival at the main road, they remove the kangas, fold them, and place them in their handbags. Then, before returning home in the morning, they cover themselves again. I asked a woman what this practice meant. "You know," she replied, "here, by the road, everyone knows you're a prostitute [malaya]. But there, in the mtaa, people don't know what you do at night. So, you have to make yourself respectable a little." In this practice, kangas cover 
up a perceived contradiction between women's desire to produce respectable futures and their use of sex work as a means of doing so. They congeal another kind of queer futurity, one whose queerness emerges with the sharp dissonance between ends and means - an exceptional, momentary queerness.

To understand this kind of queerness, it is important to think further about how alignments and misalignments of the means and ends of livelihood temporalize the future distinctly. Jane Guyer (2007) argues that the uncertainties of late capitalism have marked anthropological concerns with an "enforced presentism" and a "fantasy future", at the expense of attention to the "near future" - the concrete ways people make a tomorrow. Guyer (2007:416) emphasizes the importance of attending to "a time that is punctuated rather than enduring: of fateful moments and turning points". Practices of concealment involving kangas are part of a vast repertoire of tactics through which people resort to exceptional means to make near futures, without jeopardizing the possibility of a remoter, fantasy future. Without such tactics, the results could be drastic. When women in Mtwapa, for example, were outed as 'prostitutes' to their parents and relatives back home, they often lost any chance to return to their home communities or to build the kinds of far futures they desired. In this instance, without concealment, queer means to the near future shortcircuit long-term plans, the fantasy future. The use of the kanga outlined above is thus emblematic of attempts to produce futurity queerly, through distinct alignments of means and ends.

Numerous value-making practices that anthropologists have described in recent years have already entailed similar contradictions. For example, in the absence of employment, young men who create new ways of waiting, of spending their surplus time, whether by brewing tea, chewing khat, or consuming conspicuously, are often scolded by leaders and elders for 'wasting time', being lazy or idle (Honwana 2012; Mains 2007; Masquelier 2019; Newell 2012; Ralph 2008). So too, women who, unable to marry or feeling "stuck in the compound" (Hansen 2005), seek alternative lives through transactional sex and migration, attract social opprobrium (Cole 2010; Mojola 2014). In such contexts, as Jeremy Jones (2010) argues for Zimbabwe, "nothing is straight": a shadow economy of various "zig-zagging" survival practices operates in the "shadow" of the "normal". In my own work, I have described such moments of being out of synch with the temporal rhythms of the normative life course and respectability as "queer moments" (Meiu 2015). This then is how the dissonance between the means, outcomes, and circumstances of future-making could be read as queer, as not-yet-conscious potentialities of a queer future. 
It is precisely with the proliferation of such queer rhythms, moments, and cultural productions that a fetishistic overinvestment in the promises of the security state become saliently resonant with people's everyday struggles and concerns. Paul Amar (2013) describes the security state as based on a form of governance sustained, among other things, through moral rehabilitation, the policing of 'perverse' sexualities, 'criminal' masculinities, and the rescue of vulnerable citizens. In this context, by promising to straighten queers, the state, religious leaders, and other parastatal actors and organizations actually also promise to set queer time straight, to reclaim the linearity of temporal progress, whether in life course, work, wealth-accumulation, or national development.

If a general queerness can indeed be said to permeate conditions of everyday life today, then queerness as objectified identity - the body of the 'homosexual' - becomes an externalized representation of that condition of dissonance and, therefore also, its object-cause ("it is because of homosexuals that our futures are in jeopardy"). In other words, one can argue that the subversive means of near futures are perhaps less troublesome to people than the desire for an explicitly queer far-future, one that challenges the straight time of national utopia. And thus, the security state's legitimacy thrives off its promise to contain and eliminate bodies explicitly dedicated to such queer futurity. The 'homosexual' body is then overinvested with anxieties over an otherwise collective condition of life. It is an object through which anxieties are displaced from this collective condition and externalized onto an 'other' to be disavowed as foreign, polluting, demonical - indeed, as the anti-future.

Against this othering tactic, it is important to recognize the multiple potentialities, paths not taken, and not-yet-conscious futures that exist in every object or moment. This is what I have suggested through the example of the kanga. It is not surprising perhaps that the kanga has also of late become iconic of the moral rehabilitation campaigns of the state, churches, and civil society groups, thus adding a distinctly 'African' signifier to their crusades against the "perversions of globalization". Bi Mswafari, a Saturday evening television show that has been running for the past few years on the Kenyan national channel Citizen, features Bi Mswafari, a female marriage counsellor who, in conversation with different guests, offers moral advice on sex, love, and the family. Though contested among viewers, the show presents a set of pan-ethnic cultural values that foreground patriarchal, heterosexist national utopias. Here, Bi Mswafari and her guests appear dressed in kangas and the studio is richly decorated with numerous such fabrics. Kangas thus visually brand the African morality the show is trying to produce.

At the same time, the kanga, as its use by sex workers suggests, has also been employed in ways that seem queer, involved in forms of expression, 
concealment, and transgression emerging, ironically, as people seek to acquire normative respectability. Mwirichia's art reminds us of this capacity of the kanga, its potentiality for queerness, for a future that is more inclusive, more loving. What would it mean to embrace this queerness against normative reinscriptions of time as straight and linear, against futures that seek to rescue nativist sexuality? Queerness and the queer future are not external to normative worlds - not reducible to either LGBTQI+ people or to an imagined radical 'outside' to society and normativity - but inherent potentialities of the objects, moments, and contexts therein. Echoes here of Walter Benjamin (1999: 459) who, like Muñoz, argues that such potentialities can be activated "by a displacement of the angle of vision", so that "a positive element emerges, ... something different from that previously signified." And, if we do acknowledge the more generalized queerness of social worlds - something ethnography, like art, allows us to do - then, are we not better positioned to look into the far future?

\section{References}

Alexander, M. J. 1994. "Not just (any) body can be a citizen: The politics of law, sexuality, and postcoloniality in Trinidad and Tobago and the Bahamas." Feminist Review, 48: $5^{-23 .}$

Amar, P. 2013. The security archipelago: Human security states, sexuality politics, and the end of neoliberalism. Durham: Duke University Press.

Amory, D. 2017. "Mambo ya pwani si mchezo: Kanga cloth and the cultural construction of the Kenyan coastal identity". In Meeting of cultures at the Kenyan Coast, edited by K. Njogu and I. Cege, 36-58. Nairobi: Twaweza Communications.

Awondo, P., P. Geschiere and G. Reid. 2012. "Homophobic Africa? Toward a more nuanced view." African Studies Review, 55, 3: 145-168.

Beck, R. M. 2006. "Texts on textiles: Proverbiality as characteristic of equivocal communication at the East African coast (Swahili)." Journal of African Cultural Studies, 17, 2: 131-16o.

Benjamin, W. 1999. The arcades project. Cambridge, MA: Belknap Press.

Bosia, M. J. and M. L. Weiss. 2013. Global homophobia: States, movements, and the politics of oppression. Champaign, IL: University of Illinois Press.

Boswell, R. 2006. "Say what you like: Dress, identity, and heritage in Zanzibar." International Journal of Heritage Studies, 12, 5: 440-457.

Butler, J. 2002. "Is kinship always already heterosexual?" differences, 13, 1: 14-44.

Cole, J. 2010. Sex and salvation: Imagining the future in Madagascar. Chicago: University of Chicago Press. 
Comaroff, J. and J. Comaroff. 2001. "Naturing the nation: Aliens, apocalypse, and the postcolonial State." Social Identities, 7, 2: 233-265.

Cynn, C. 2018. Prevention: Gender, sexuality, HIV, and the media in Côte d'voire. Ohio: Ohio State University Press.

Dankwa, S. O. 2021. Knowing women: Same-sex intimacy, gender, and identity in postcolonial Ghana. Cambridge: Cambridge University Press.

Epprecht, M. 2007. Heterosexual Africa? The history of an idea from the age of exploration to the age of AIDS. Athens: Ohio University Press.

Ferguson, J. 2006. Global shadows: African in the neoliberal world order. Durham: Duke University Press.

Freeman, E. 2007. "Introduction. Special issue: Queer temporalities." GLQ: A Journal of Gay and Lesbian Studies, 13, 2/3: 159-176.

Gaudio, R. P. 2009. Allah made us: Sexual outlaws in an Islamic African city. Sussex: Wiley-Blackwell.

Guyer, J. I. 2007. "Prophecy and the near future: Thoughts on macroeconomic, evangelical, and punctuated time." American Ethnologist, 22, 2: 375-421.

Halberstam, J. 2005. In a queer time and place: Transgender bodies, subcultural lives. Durham, NC: Duke University Press.

Hansen, K. T. 2005. "Getting stuck in the compound: Some odds against social adulthood in Lusaka, Zambia." Africa Today, 51, 4:3-16.

Honwana, A. 2012. The time of youth: Work, social change, and politics in Africa. Sterling, VA: Kumarian Press.

Jones, J. L. 2010. "Nothing is straight in Zimbabwe': The rise of the kukiya-kiya economy 2000-2008." Journal of Southern African Studies, 36, 2: 285-299.

Koselleck, R. 1979. Futures past: On the semantics of historical time. New York: Columbia University Press.

Lorway, R. 2015. Namibia's rainbow project: Gay rights in an African nation. Bloomington: Indiana University Press.

McCurdy, S. 2006. "Fashioning sexuality: Desire, Manyema ethnicity, and the creation of the Kanga, ca. 1880-190o." International Journal of African Historical Studies, 39, 3: 441-469.

M'Baye, B. 2013. "The origins of Senegalese homophobia: Discourses on homosexuals and transgender people in colonial and postcolonial Senegal." African Studies Review, 56, 2: 109-128.

Mains, D. 2007. "Neoliberal times: Progress, boredom, and shame among young men in urban Ethiopia." American Ethnologist, 34, 4: 659-673.

Makumbi J. N. 2018. Kintu. London: Oneworld.

Masquelier, A. 2019. Fada: Boredom and belonging in Niger. Chicago: University of Chicago Press. 
Meiu, G. P. 2015. "Beach-boy elders' and 'young big-man': Subverting the temporalities of ageing in Kenya's ethno-erotic economies." Ethnos, 80, 4: 472-496.

Mojola, S. A. 2014. Love, money, and HIV: Becoming a modern African woman in the age of AIDS. Berkeley: University of California Press.

Muñoz, J. E. 2009. Cruising utopia: The then and there of queer futurity. New York: New York University Press.

Ndjio, B. 2016. "The nation and its undesirable subjects: Homosexuality, citizenship, and the gay 'other' in Cameroon." In The culturalization of citizenship: Belonging and polarization in a globalizing world, edited by J. W. Duyvendak, P. Geschiere and E. Tonkens, 115-136. London: Palgrave Macmillan.

Newell, S. 2012. The modernity bluff: Crime, consumption, and citizenship in Côte d'Ivoire. Chicago: University of Chicago Press.

Nyamnjoh, F. 2006. Insiders and outsiders: Citizenship and xenophobia in contemporary South Africa. London: Zed Books.

Nyanzi, S. 2014. "Queering queer Africa." In Reclaiming Afrikan: Queer perspectives on sexual and gender identities, edited by Z. Matebeni, 65-68. Cape Town: Modjaji Books.

Ombogo M. 2019. "The artpreneur out to spark a revolution using the kanga." Standard, 27 March. www.standardmedia.co.ke [5 December 2019].

Ralph, M. 2008. "Killing time." Social Text, 26:1-29.

Reid, G. 2013. How to be a real gay: Gay identities in small-town South Africa. Scottsvile: KwaZulu-Natal Press.

Smith, J. H. 2008. Bewitching development: Witchcraft and the reinvention of development in neoliberal Kenya. Chicago: University of Chicago Press.

van Klinken, A. 2019. Kenyan, Christian, queer: Religion, LGBT activism, and arts of resistance in Africa. Pennsylvania: Pennsylvania State University Press.

Wainaina, B. 2014. "We must free our imagination." YouTube video (six parts). https:// www.youtube.com/ watch?v=8uMwppw5AgU\&list=PLlntFbWEgLBTgFBzcqYQoLC XHZXAqiQmm.

Wiegman, R. and E. A. Wilson. 2015. "Introduction: Antinormativity's queer conventions." differences, 26, 1: 1-25. 